\title{
Analisis Kelayakan Finansial Usaha Perikanan Pole and Line di PPN Kota Ternate
}

\author{
Sayang Bidul ${ }^{1}$, Umar Tangke ${ }^{2 \bowtie}$, dan Ibnu W. Laitupa ${ }^{2}$ \\ 1 Mahasiswa Program Studi Teknologi Hasil Perikanan, Fakultas Pertanian dan Perikanan, Universitas Muhammadiyah \\ Maluku Utara. Ternate, Indonesia. \\ ${ }^{2}$ Staf Pengajar Program Studi Teknologi Hasil Perikanan, Fakultas Pertanian dan Perikanan, Universitas Muhammadiyah \\ Maluku Utara. Ternate, Indonesia. \\ Email : umbakhaka@gmail.com
}

Korespondensi : Umar Tangke, Universitas Muhammadiyah Maluku Utara. Ternate, Indonesia,
Email : umbakhaka@gmail.com

\begin{abstract}
ABSTRAK
Produksi ikan cakalang pada dasarnya merupakan hasil proses penagkapan yang dilakukan oleh para nelayan dengan menggunakan berbagai alat tangkap baik yang bersifat tradsional maupun modern. Ikan cakalang termasuk dalam family Scombridae, merupakan ikan pelagis besar yang hidup secara bergerombol. Usaha penangkapan ikan cakalang dengan Pole And Line membutuhkan investasi yang besar. Dengan demikian analisis finansial terhadap usaha ini penting dilakukan untuk mengetahui apakah lebih menguntungkan jika menginvestasikan uang pada kegiatan penangkapan ikan cakalang dengan pole and line atau lebih baik pada usaha lain. Hal ini yang mendasari pelaksanaan penelitian ini, dengan tujuan menghitung keuntungan dan kelayakan usaha perikanan cakalang dengan alat tangkap Pole And Line di PPN Kota Ternate. Penelitian ini dilaksanakan bulan April- Mei 2021 sentral di PPN Kota Ternate dan dalam penelitian ini ada data pengamatan Kapal pole and line yang beroperasi di PPN Ternate, salah satunya kapal KM. Inka Mina 992 dengan tanda selar No 924 M.M e, terbuat dari kayu besi dengan tempat pemancing dihaluan kapal. Dimensi KM. Inka Mina 992 adalah panjang (L) 19 m, lebar (B) 3, 8 dan tinggi (D) 1,75 m. Kapasitas muatan kapal 37 GT, dengan mesin utama merk Mistsubishi 6D15 berkekuatan 120 PK. Terdapat empat metode yang biasa dipertimbangkan dalam penilaian aliran kas dari suatu investasi agar dapat mengukur nilai investasi mana yang layak untuk dikembangkan dari ke-5 unit usaha pole and line. Keempat metode yang digunakan dalam penelitian ini adalah Net Present Value (NPV), Internal Rate of Return (IRR), Benefit Cost Ratio (B/C) dan Payback Period (PP).
\end{abstract}

Keyword: Pole and line, Cakalang, PPN Ternate, Scombridae

\section{PENDAHULUAN}

Pelabuhan Perikanan Nusantara Ternate (PPN) Ternate di bangun 1978 dengan berbagai sarana dasar, sarana fungsional dan sarana penunjang. PPN Ternate pada awalnya berdirinya adalah pelabuhan perikanan pantai (type C), pada tahun 2001 dinaikan statusnya menjadi Pelabuhan Perikanan Nusantara (type B). Pelabuhan Perikanan Nusantara (PPN) memiliki peranan sangat penting dalam kegiatan ekonomi Perikanan di Kota Ternate. Pelabuhan Perikanan Nusantara (PPN) ini sangat berperan untuk meningkatkan produksi ikan, pemasukan devisa, membuka lapangan pekerjaan, dan maupun peningkatkan pendapatan daerah. Selain itu PPN ini juga mempunyai memiliki fasilitasnya sebagai penunjang tata operasional kapal-kapal yang ada di PPN Kota Ternate.

Kegiatan penangkapan ikan merupakan aktivitas yang dilakukan untuk mendapatkan sejumlah hasil tangkapan, yaitu berbagai jenis ikan untuk memenuhi permintaan sebagai sumber makanan dengan menggunakan berbagai jenis alat tangkap. Adanya permintaan menyebabkan terjadinya siklus ekonomi dimana akan terjadi keuntungan dan kerugian, sehingga aktivitas penangkapan produksi ikan untuk meraih keuntungan yang sebesar-besarnya oleh pelaku usaha penangkapan ikan.

Pole and line adalah jenis alat penangkapan dengan mengunakan pancing yang di khususkan untuk menangkap ikan cakalang yang banyak digunakan diperairan Indonesia lebih khsusnya di Kota Ternate. Pole and line umum digunakan untuk menangkap ikan cakalang sehingga dengan kata 
perikanan pole and line sering pengertian kita kearah perikanan cakalang, sungguh pun dengan cara Pole And Line yang dilakukan penangkapan, Albacore, Mackerel dan lainnya (Ayodhoya, 1981).

Produksi ikan cakalang pada dasarnya merupakan hasil proses penagkapan yang dilakukan oleh para nelayan dengan menggunakan berbagai alat tangkap baik yang bersifat tradsional maupun modern. Alat tangkap yang umum digunakan para nelayan dikawasan timur Indonesia salah satunya pole and line. Sementara dalam operasi penangkapan dengan mengunakan alat tangkap pole and line disamping dibutuhkan saranan alat tangkap berupa kapal, pancing dan umpan berupa ikan hidup juga di perlukan alat bantu rumpon sebagai saranan untuk mengkonsentrasi ikan (Winsaro, 2004).

Ikan cakalang termasuk dalam family Scombridae, merupakan ikan pelagis besar yang hidup secara bergerombol, (Matsumoto 1984 et al.; FAO 1983; Collette dan Nauen 1993). Ikan cakalang terdiri dari satu spesies yaitu Katsuwonus pelamis (FAO 1983). Penyebarannya sangat luas di seluruh Samudra Pasifik, di perairan tropis dan sub tropis (Scaever 2001; Grande et al. 2010). Ikan cakalang terdapat hampir di seluruh perairan Indonesia, terutama di Bagian Timur Indonesia. Daerah penyebaran ikan cakalang hampir di seluruh perairan Provinsi Maluku (Kementrain Kelautan dan Perikanan RI, 2013).

Usaha penangkapan ikan cakalang dengan Pole And Line membutuhkan investasi yang besar. Dengan demikian analisis finansial terhadap usaha ini penting dilakukan. Soeharto (1999) menjelaskan bahwa keputusan melakukan investasi dengan biaya yang besar untuk mendapat keuntungan dalam jangka panjang, berdampak besar bagi kelangsungan usaha. Oleh karena itu, sebelum mengambil keputusan jadi tidaknya investasi dijalankan, salah satu syarat terpenting adalah mengkaji aspek finansial. Dalam kegiatan bisnis, aspek finansial adalah inti dari keseluruhan aspek yang dianalisis. Aspek finansial berkaitan dengan penentuan kebutuhan jumlah dana dan pengalokasiannya sehingga memberikan keuntungan yang menjanjikan bagi pengusaha atau investor. Aspek finansial ini menyangkut perbandingan antara pengeluaran uang dengan pemasukan atau return dalam suatu kegiatan bisnis. Dalam analisis finansial kita menghitung baik benefit dan biayabiaya perusahan untuk kepentingan individu atau perusahan.

Aspek finansial berhubungan dengan analisis biaya dan pendapatan, kelayakan usaha dan lainnya. Analisis kelayakan usaha perlu dilakukan untuk mengetahui apakah lebih menguntungkan jika menginvestasikan uang pada kegiatan penangkapan ikan cakalang dengan pole and line atau lebih baik pada usaha lain. Hal ini yang mendasari pelaksanaan penelitian ini, dengan tujuan menghitung keuntungan dan kelayakan usaha perikanan cakalang dengan alat tangkap Pole And Line di PPN Kota Ternate. Penelitian dilaksanakan di PPN Kota Ternate adalah untuk menganalisis besarnya biaya, keuntungan dan tingkat kelayakan finasial dari usaha perikanan PPN Kota Ternate.

\section{METODE PENELITIAN}

Penelitian ini dilaksanakan selama 2 bulan pada bulan April sampai Mei 2021 di PPN Ternate, Kecamatan Ternate selatan, Provinsi Maluku Utara. Alat dan bahan yang digunakan dalam penelitian ini terdiri dari alat tulis menulis, 1 unit computer, kamera digital, dan kuisioner. Prosedur pengambilan data yang dilakukan dalam penelitian ini adalah survey, observasi lapangan dan wawancara langsung pada lokasi penelitian serta wawancara dengan pihak PPN Ternate, nelayan, nelayan penjual di Pelabuhan Perikanan Nuantara Ternate (PPN) untuk mendapatkan data primer dan sekunder dalam penelitian. Selain itu penelusuran data data sekunder dilakukan dengan meminta data produksi tahun 2015-2019 di PPN Ternate.

Metode yang digunakan dalam penelitian ini adalah metode deskriptif yang bersifat survei. Survei adalah penyelidikan yang diadakan untuk memperoleh fakta-fakta dari gejala-gejala yang ada dan mencari keterangan-keterangan secara faktual, baik tentang institusi sosial, ekonomi, atau politik dari suatu kelompok ataupun suatu daerah (Nazir, 2005). Survei yang dilakukan dalam penelitian ini bertujuan untuk memperoleh keterangan yang faktual dari suatu kelompok mengenai tingkat kesejahteraan keluarganya. Kelompok yang diambil sebagai subyek pengkajian adalah nelayan Pole and line di PPN Kota Ternate, dengan metode pengambilan sampel yang digunakan adalah metode sensus, dimana di khususkan kepada alat tangkap Pole and Line. Data yang digunakan dalam penelitian ini merupakan data primer dan data sekunder. Data primer dikumpulkan melalui pengamatan langsung di lapangan dan kuisioner oleh responden. Data sekunder diperoleh melalui studi pustaka dan instansi-instansi pemerintahan yang terkait dengan penelitian. Data sekunder sebagai data pelengkap dan penunjang. 
Analisis data merupakan bagian yang penting dalam metode ilmiah, karena analisis data dapat menyederhanakan data menjadi bentuk yang lebih mudah dipahami dan diinterpretasikan. Analisis data adalah mengelompokkan, memanipulasi dan menyingkat data, sehingga mudah untuk dibaca. Data dan informasi yang terkumpul dianalisis berdasarkan analisis teknis dan analisis finansial.

1. Kondisi Sosial Ekonomi Responden

Menurut Masri (2010), dalam menganalisis data pada kondisi sosial ekonomi digunakan analisis deskriptif untuk menggambarkan karakteristik suatu variabel, mengetahui keterkaitan antar berbagai variabel tersebut. Dalam hal ini berbagai variabel yang mempunyai keterkaitan atau hubungan antar kondisi nelayan dengan aspek sosial dan ekonomi suatu nelayan. Melalui pendekatan ini peneliti mengadakan wawancara/kuisioner terhadap para nelayan.

2. Analisis teknis

Menurut Isnaini dan Sobari (2009), analisis teknis dilakukan dengan metode deskriptif dengan memberikan gambaran kegiatan usaha perikanan tangkap Pole and Line di PPN Kota Ternate. Unit penangkapannya meliputi konstruksi alat tangkap Pole and Line, operasi Pole and Line dan hasil tangkapan Pole and Line.

3. Analisis finansial

Analisis finansial usaha dilakukan untuk mengukur kinerja usaha penangkapan ikan dengan menghitung nilai-nilai NPV (net present value), B/C Ratio (net benefit cost ratio), IRR (internal rate of return), dan PP (payback period). Berikut adalah penjelasan singkat tentang cara penghitungan indikator finansial tersebut:

a. NPV (Net Present Value), NPV yaitu selisih antara Present Value dari investasi dan nilai sekarang dari penerimaan-penerimaan kas bersih (arus kas operasional maupun arus kas terminal) di masa yang akan datang. Untuk menghitung nilai sekarang perlu ditentukan tingkat bunga yang relevan. Analisa NPV dapat diketahui dengan rumus:

$$
\begin{aligned}
& \mathrm{NPV}=\sum_{\mathrm{t}=1}^{\mathrm{n}} \frac{\mathrm{CFt}}{(1+\mathrm{i})} \mathrm{t}-\mathrm{Co} \\
& \text { Dimana: } \\
& \mathrm{CFt}=\text { aliran kas per tahun pada periode } \mathrm{t} \\
& \mathrm{Co} \quad=\text { investasi awal pada tahun ke-0 } \\
& \mathrm{I} \quad=\text { suku bunga } \\
& \mathrm{t} \quad=\text { tahun ke } \\
& \mathrm{n} \quad=\text { jumlah tahun } \\
& \text { Pengambilan keputusan: } \\
& \text { Jika, NPV > L; maka usaha tersebut layak, } \\
& \text { NPV }=0 \text {; maka usaha tersebut dapat layak, } \\
& \text { NPV }<1 \text {; maka usaha tersebut tidak layak (Umar, 2003). }
\end{aligned}
$$

b. B/C Ratio dimaksudkan untuk mengetahui besarnya nilai perbandingan penerimaan dan biaya produksi yang digunakan. Rumus perhitungan ini seperti dikemukakan Hermanto (1998) adalah sebagai berikut:

$$
\mathrm{B} / \mathrm{C} \text { Ratio }=\frac{\text { Total penerimaan }}{\text { Total biaya }}
$$

Kriteria yang digunakan adalah:

$\mathrm{B} / \mathrm{C}$ ratio $>1$, berarti usaha menghasilkan keuntungan sehingga layak untuk dijalankan

$\mathrm{B} / \mathrm{C}$ ratio $=1$, berarti usaha tidak untung dan tidak rugi (impas) $\mathrm{B} / \mathrm{C}$ ratio $<1$, berarti usaha mengalami kerugian sehingga tidak layak untuk dijalankan.

c. IRR (Internal Rate of Return), Menurut Dahlan (2011), IRR adalah merupakan tingkat bunga yang akan menjadikan jumlah nilai sekarang dari produk sama dengan jumlah nilai sekarang dari pengeluaran modal. Nilai IRR dapat dihitung dengan menggunakan rumus:

$$
\begin{aligned}
& \text { IRR }=i_{1}+\frac{N P V_{1}}{N P V 1-N P V 2}\left(i_{2}-i_{1}\right) \\
& \text { Dimana: } \\
& \mathrm{i}_{1}=\text { tingkat bunga ke-1 } \\
& i_{2}=\text { tingkat bunga ke-2 }
\end{aligned}
$$


$\mathrm{NPV}_{1}=\mathrm{NPV}$ pada tingkat bunga $\mathrm{i}_{1}$

$\mathrm{NPV}_{2}=\mathrm{NPV}$ pada tingkat bunga $\mathrm{i}_{2}$

Usaha dikatakan layak jika, IRR > discount rate, sedangkan usaha dikatakan tidak layak jika IRR < discount rate.

d. PP (Payback Period), Payback Period merupakan suatu cara penilaian investasi yang didasarkan pada pelunasan biaya investasi oleh keuntungan atau dengan kata lain waktu yang diperlukan untuk mengembalikan modal yang ditanam (Umar, 2003).

Payback Period $=$ modal $/$ keuntungan

\section{HASIL DAN PEMBAHASAAN}

\subsection{Deskripsi Teknologi Penangkapan Ikan Cakalang}

Teknologi penangkapan yang digunakan untuk menangkap jenis ikan pelagis besar khususnya ikan cakalang di daerah timur Indonesia, umumnya Maluku, Maluku Utara dan Papua adalah pole and line atau lebih dikenal dengan nama huhate, pukat cincing dan hand line. Sebagian besar kapal penangkap sudah dilengkapi dennga peralatan navigasi berupa GPS dan fish finder GPS atau global positioning system berfungsi untuk memplot posisi kapal dan daerah penangkapan dan fish finder berfungi untuk menemukan gerombolan ikan. Hasil tangkapan dari semua unit penangkapan untuk tujuan konsumsi maupun tujuan komersil baik untuk kebutuhan pasar lokal maupun ekspor (Waileruny, 2014).

Pole and line adalah jenis alat penangkapan ikan yang terdiri dari bambu sebagai joran/tongkat dan tali sebagai tali pancing. Pada tali pancing ini dikaitkan mata pancing yang tidak berkait. Penggunaan mata pancing yang tidak berkait dimaksud agar ikan yang ditangkap dapat muda kepas, alat ini digunakan secara perorangan sehingga salah satu faktor yang mempergaruhi suksesnya penangkapan adalah keterampilan induvidu dari para pemancig, selain masalah-masalah lain seperti tersediahnya umpan yang cukup, banyak tidaknya gerombolan ikan di daerah penangkapan.

Menurut Hutama, et al., (2017), alat tangkap pole and line merupakan salah satu alat tangkap yang ramah lingkungan, ini di karenakan sangat selektif, sehingga menjadikannya sebagai salah satu alat tangkap yang direkomendasikan untuk digunakan. Keberadaan alat tangkap tersebut belum maksimal digunakan karena ada beberapa syarat pemancing dalam hal ini pemancing harus berpengalaman dalam menyiapkan umpan, daerah penangkapan yaitu untuk mendapatkan hasil tangkap sesuai target tangkapan yakni jenis ikan pelagis besar, distribusi ikan serta persyaratan umpan hidup agar pada saat di fishing ground umpan yang digunakan masih segar sehingga dapat menarik perhatian ikan target.

Kapal pole and line yang beroperasi di PPN Ternate, salah satunya kapal KM. Inka Mina 992 dengan tanda selar No 924 M.M e, terbuat dari kayu besi dengan tempat pemancing dihaluan kapal. Dimensi KM. Inka Mina 992 adalah panjang (L) 19 m, lebar (B) 3, 8 dan tinggi (D) 1,75 m. Kapasitas muatan kapal 37 GT, dengan mesin utama merk Mistsubishi 6D15 berkekuatan 120 PK. Haluan kapal pole and line di desain khusus dan agak tinggi dan terdapat terdapat flying deck yang memudahkan pemancing untuk melakukan operasi penangkapan dan ikan yang tertangkap dapat meluncur turun ke bagian tengah kapal dekat bak penumpang hasil tangkapan sehingga memudahkan proses penanganan hasil tangkapan.

Kapal KM. Inka Mina 992 dan jenis pole and line pada umumnya di lengkapi dengan pipa-pipa penyemprot air yang ujungnya dipipihkan untuk memaksimalkan jangkuan semprotan air. Pipa ini terletak di haluan kapal dibawah flyin beck atau tempat duduk pemancing dengan jumlah 8 buah, masing-masing 2 di samping kiri dan kanan haluan kapal dan 4 di haluan. Kapal KM. Inka Mina 992 dilengkapi dengan bak umpan (live bait tank) terletak pada lambung kapal dengan jumlah 2 unit berukuran sama yakni panjang 1,5 m dan tinggi 1,5 m, serta memiliki kapasitas umpan maksimal 20 ember atau kurang lebih 400 liter. Bak umpan merupakan ciri khas kapal pole and line, yang dilengkapi dengan lubang pemasukan dan pengeluaran air yang berfungsi sebagai sistem sirkulai air. Untuk memperlancar sirkulasi dalam tiap bak umpan maka terdapat satu lubang pemasukan yang dipasangi belahan bambu yang menghadap ke haluan kapal, sehingga air akan masuk bila kapal bergerak maju dan terdapat tujuh lubang lainnya yang dilapisi dengan saringan sebagai keluarnya air. Untuk mengeringkan bak umpan setelah digunakan, maka belahan bambu tersebut diputar menghadap ke buritan kapal. 
Untuk menampung hasil tangkapan, maka kapal Kapal KM. Inka Mina 992 dilengkapi dengan 1 buah palka penyimpan hasil tangkapan dengan kapsitas 2 ton yang berukuran panjang serta lebar $1 \mathrm{~m}$ dan tinggi $1.2 \mathrm{~m}$, palka dapat berfungsi sebagai tempat penyimpanan es. Bagian-bagian kapal lainnya dalah ruang kemudi, ruang mesin, tangki bahan bakar yang berkapasitas 400-1.000 liter, ruang istrahat $\mathrm{ABK}$, bak air bersih, dapur dan WC.

\subsection{Operasi persiapan penangkapan}

Untuk kelancaran dan keberhasilan operasi penangkapan ikan. Maka sebelum berangkat ke fishing ground, dilakukan berbagai persiapan baik teknis maupun non teknis.

\subsubsection{Persiapan teknis}

Persiapan teknis yang dilakukan adalah memuat bahan bakar (solar) dan es balok. Untuk satu kali operasi penangkapan dibutuhkan 400 - 8000 liter bensin dan 40 - 68 balok es, sesuai dengan modal yang tersedia. Persiapan yang lain yaitu pemeriksaan alat-alat penangkapan (Joran, tali dan mata pancing), serok pengambil umpan, alat pelempar umpan (sibu-sibu), pemeriksaan mesin, peralatan navigasi (kompas dan peta pelayaran).

\subsubsection{Persiapan non teknis}

Persiapan non teknis yang dilakukan sebelum kapal berangkat ke fishing ground meliputi penyediaan bahan logistik (ransum) seperti beras, ikan kering, mie instant, kopi, teh, rokok dan lainlain.

\subsection{Pengelolaan Usaha Pole and Line}

Usaha perikanan tangkap pole and line yang ber home base di PPN Ternate cukup banyak, dimana pemilik usaha memulai usahanya dengan modal sendiri dan hanya memiliki satu unit armada penangkapan yang kemudian terus berkembangan dengan cukup baik sehingga jumlah armadanya meningkat hingga sampai saat ini di seluruh pengelolaan unit usaha pole and line diatur oleh pemilik pribadi maupun dari bantuan dari DKP Kota Ternate.

Hasil penelitian didapat bahwa pemilik usaha hanya sebagai pengawas terhadap setiap unit penangkapan karena biaya investasi, biaya tetap dan biaya variabel telah ditanggung pemilik sedangkan ABK bertugas untuk melakukan operasi penangkapan dan membantu dalam proses pemasaran hasil tangkapan. Dalam menjalankan usaha pole and line ada beberapa perencanaan yang sangat penting meliputi modal awal (barang investasi), tenaga kerja (ABK), jumlah trip, biaya-biaya yang akan dikeluarkan, serta penentuan wilayah penangkapan (fishing ground).

\subsection{Sumberdaya Manusia}

Sumber daya manusia dalam konteks ini adalah tenaga kerja, termasuk pemilik dan anak buah kapal (ABK) yang melakukan kegiatan penangkapan di laut. Jumlah tenaga kerja dalam usaha perikanan pole and line dipengaruhi oleh ukuran kapal. Selain itu masing-masing tenaga kerja memiliki pembagian tugas sesuai dengan ketrampilan yang di miliki pembagian tugas dengan jabatanya sewaktu operasi penangkapan. Rata-rata ABK yang bekerja pada kapal pole and line di PPN Ternate berjumlah 16-20 orang, dengan rincian: 1 nahkoda, $1 \mathrm{KKM} / \mathrm{masinis}, 1-2$ orang boy-boy, 1 orang koki dan 16 orang orang pemancing, dengan tugas dan tanggung jawab masing-masing. Pembagian tugas dan tanggung jawabnya sebagai berikut:

1) Kapten, bertanggung jawab sepenuhnya terhadap kapal, dan secara keseluruhan atas keberhasilan operasi penangkapan. Seornag kapten kapal harus memiliki pengetahuan tentang pelayanan dan navigasi, pengetahuan tentang kondisi perairan, keadaan angina dan pengetahuan tentang sifat ikan cakalang.

2) Juru mudi, bertugas membantu kapten kapal dalam mengemudi kapal selama operasi di laksanakan.

3) Bagian mesin (bass) bertanggung jawab atas kerja mesin kapal, baik mesin utama maupun mesin bantu

4) Boy-boy, bertanggung jawab untuk melakukan pengintaian gerombolan ikan, menarik gerombolan ikan mendekati kapal dengan teknik pelemparan ikan, pelemparan umpan, mengatur efisiensi dan aktivitas pengunaan umpan.

5) Pemancing, bertugas melakukan pemancing yaitu dengan memindahkan ikan dari laut ke kapal sebanyak-banyaknya, untuk itu seorang pemancing harus memiliki keahlian, kecepatan, ketelitian, 
dan kesabaran. Pada kapal Pole and Line, pemancing dibagi menjadi 3 yaitu pemancing kelas 1 yang suda berpengelaman pada sudut kiri dan kanan flying deck: pemancing kelas II pada bagian depan haluan dan pemancing III agak kebelakang dari haluan.

6) Koki, bertanggung jawab terhadap penyediaan konsumsi bagi seluruh crew kapal.

Dalam pembagian tugas ini crew kapal tidak mutlak harus pada posisi tugas dan tanggung jawabnya karena kadang-kadang ada pekerjaan yang memerlukan kerjasama, misalnya pada saat pemancing, penyediaan konsumsi dll.

\subsection{Frekeunsi, Musim dan Lokasi Penangkapan}

Frekuensi melaut kapal KM. Inka Mina 992 yang ber home base PPN Ternate adalah 3-6 hari dengan waktu operasi penangkapan dihitung dengan satuan per trip. Jumlah frekuensi melaut tergantung pada musim ikan dan musim kurang, juga ketersediaan modal dan tenaga kerja. Pada musim ikan rata-rata jumlah trip penangkapan per unit berkisar 3 - 6 trip/bulan, sedangkan pada musim kurang ikan berkisar 1-3 trip/bulan.

Daerah penangkapan untuk jenis tuna kecil atau bonito terbatas pada perairan bersifat oceanis. Ikan cakalang (Katsuwonus pelamis) hidup bergerombol di daerah perairan pantai sampai di laut lepas. Daerahnya di tandai dengan keadaan air yang jernih dan tidak berkarang, jauh dari muara sungai. Daerahnya merupakan perairan yang tenang tidak bergelombang besar dan bukan daerah angina topan. Daerah penangkapan ikan cakalang yang terkenal ialah Maluku di sekitar pulau Buru, pulau Seram, pulau Ternate dan di Banda sampai sekitar Kepulauan Tanimbar dan Aru (Usemahu dan Tosmasila, 2001).

Hasil penelitian menunjukan bahwa tangkapan tertinggi nelayan KM. Inka Mina 992 seperti lazimnya nelayan-nelayan di daerah lain juga mengenal 3 musim penangkapan, yaitu: musim puncak pada bulan September sampai Nopember, pada musim ini rata-rata nelayan dapat memperoleh hasil antara 3-6 ton/trip; musim biasa pada bulan Desember sampai April, dengan hasil tangkapan ratarata 2 - 5 ton/trip; dan musim paceklik pada bulan Mei sampai Agustus, dengan hasil tangkapan 0.5 - 1 ton/trip. Pada musim paceklik, biasanya nelayan jarang yang turun melaut, karena angin terlalu kencang. Oleh karena itu, pada saat musim paceklik biasanya kapal diistirahatkan dan diperbaiki (dok) bila ada kerusakan-kerusakan.

\subsection{Pemesaran Hasil Tangkap}

Pemasaran ikan cakalang (Katsuwonus pelamis) merupakan usaha yang menjanjikan bagi masyarakat nelayan, karena harga jual yang cukup tinggi dan pasar yang sangat terbuka, dapat dipasarkan dalam bentuk segar, beku maupun olahan. Proses distribusi ikan cakalang dari nelayan kepada konsumen memerlukan berbagai kegiatan fungsional pemasaran yang ditujukan untuk memperlancar proses penyaluran secara efektif dan efisien guna memenuhi kebutuhan konsumen. Kegiatan fungsional tersebut dilakukan oleh lembaga-lembaga pemasaran yang membentuk suatu rantai pemasaran tertentu. Setiap rantai pemasaran yang terbentuk pada pemasaran ikan cakalang akan memiliki karakteristik tersendiri, yang akan mempengaruhi tingkat keuntungan dan efesiensi dari suatu sistem jaringan pemasaran. Distribusi pemasaran produk perikanan Kota Ternate tersebar hingga ke Bitung, Makassar, Surabaya dan Jakarta. Volume pemasaran tertinggi dan kontinyu dalam distribusi keluar kota adalah ke wilayah Jakarta.

\subsection{Biaya dan Pendapatan}

Analisis Biaya dan Pendapatan dimaksudkan untuk mengetahui besarnya perubahan laba jika biaya operasi penangkapan, volume dan harga pemasaran berubah, dengan demikian sebelum menghitung laba maka dilakukan analisis terhadap biaya-biaya terlebih dahulu. Jenis biaya yang umum diketahui yaitu biaya investasi atau modal, biaya tetap dan biaya operasi yakni biaya produksi atau lebih dikenal dengan biaya variabel.

\subsubsection{Investasi}

Investasi merupakan modal kerja parmanen atau biaya-biaya yang dikeluarkan untuk mendapatkan barang investasi. Dalam usaha perikanan, barang investasi berupa kapal, mesin pengerak, mesin bantu, alat tangkap dan peralatan navigasi yang diperlukan untuk menghasilkan hasil tangkapan. Komponen biaya investasi terbesar untuk perikanan pole and line adalah kapal sebesar 
$67.4 \%$ diikuti oleh mesin induk $30.6 \%$ dan $2.0 \%$ sisanya untuk lampu. Pompa sirkulasi, lampu kapal, alat navigasi dan alat pancing (Tabel 1).

Tabel 1. Besarnya Investasi Kapal Kapal KM. Inka Mina 992

\begin{tabular}{clcrr}
\hline No & Jenis Barang & Jumlah (unit) & \multicolumn{1}{c}{ Nilai (Rp.) } & \multicolumn{1}{c}{$(\%)$} \\
\hline 1 & Kapal Ikan & 1 & $550,000,000$ & 67.4 \\
2 & Mesin Utama & 1 & $250,000,000$ & 30.6 \\
3 & Mesin Lampu & 1 & $5,000,000$ & 0.6 \\
4 & Pompa Sirkulasi & 1 & $3,200,000$ & 0.4 \\
5 & Lampu Kapal & 10 & 560,000 & 0.1 \\
6 & Alat Navigasi & 3 & $5,670,000$ & 0.7 \\
7 & Alat Pancing & 20 & $2,000,000$ & 0.2 \\
\hline \multicolumn{2}{r}{} & Total (Rp.) & $\mathbf{8 1 6 , 4 3 0 , 0 0 0}$ & $\mathbf{1 0 0}$ \\
\hline
\end{tabular}

Tabel 1. Menunjukkan bahwa alat tangkap pole and line merupakan sederhana dengan biaya yang sangat rendah. Alat tangkap ini juga memiliki umur ekonominya pendek yakni maskimal 2 tahun. Komponen biaya investasi untuk mesin bantu dan alat navigasi semua kapal pole and line yang ada di PPN Ternate hampir sama besar karena jenis dan ukuran yang digunakan pada setiap kapal pole and line hampir sama. Besarnya biaya investasi pada perikanan pole and line ditentukan oleh besarnya kapal yang digunakan, dimana alat tangkap pada perikanan pole and line walaupun merupakan salah satu faktor penentu keberhasilan dalam operasi penangkapan namun dari sisi investasi membutuhkan biaya yang kecil yakni $0.2 \%$.

\subsubsection{Biaya tetap}

Biaya tetap (fixed cost) merupakan biaya yang jumlahnya tetap selama periode waktu tertentu dan tidak bergantung pada volume produksi. Biaya tetap pada usaha perikanan pole and line adalah biaya penyusutan, biaya perbaikan dan perawatan serta biaya administrasi. Perhitungan biaya penyusutan berdasarkan metode garis lurus yaitu besarnya biaya investasi setiap unit produksi dibagi dengan umur ekonomi barang tersebut. Pada penelitian ini didapatkan bahwa umur ekonomi untuk kapal pole ang line 20 tahun, mesin utama 10 tahun, mesin bantu 8 tahun, lampu kapal 2 tahun peralatan, peralatan navigasi 8 tahun dan alat tangkap 2 tahun. Besarnya biaya tetap, setiap unit usaha disajikan pada Tabel 2 .

Tabel 2. Biaya Tetap Kapal KM. Inka Mina 992

\begin{tabular}{|c|c|c|c|c|}
\hline \multicolumn{5}{|c|}{ Biaya Tetap (Rp/Tahun) } \\
\hline No & Jenis Barang & Jumlah & $\begin{array}{l}\text { Masa Pakai } \\
\text { (Tahun) }\end{array}$ & Penyusutan \\
\hline 1 & Kapal Ikan & 1 & 20 & $27,500,000$ \\
\hline 2 & Mesin Utama & 1 & 10 & $25,000,000$ \\
\hline 3 & Mesin Lampu & 1 & 8 & 625,000 \\
\hline 4 & Pompa Sirkulasi & 1 & 8 & 400,000 \\
\hline 5 & Lampu Kapal & 10 & 2 & $2,800,000$ \\
\hline 6 & Alat Navigasi & 3 & 8 & $2,126,250$ \\
\hline 7 & Alat Pancing & 20 & 2 & $20,000,000$ \\
\hline 1 & Perbaikan dan perawatan & & & $15,328,000$ \\
\hline \multirow[t]{2}{*}{2} & Administrasi & & & $9,250,000$ \\
\hline & & & Total (Rp) & $103,029,250$ \\
\hline
\end{tabular}

\subsubsection{Biaya Variabel}

Biaya variabel atau biaya operasi adalah biaya-biaya yang langsung berhubungan dengan proses produksi (Stanton, 1985 dalam Waileruny dan Matruty, 2015). Pada usaha perikanan tangkap biaya variable merupakan biaya-biaya yang dikeluarkan dalam melakukan operasi penangkapan ikan. Dalam perikanan pole and line biaya variable meliputi biaya Konsumsi, bahan bakar (BBM), upah nelayan, es, air minum dan lain-lain. Besarnya setiap komponen biaya variabel KM. Inka Mina 992 disajikan pada Tabel 3. Sedangkan perbandingan biaya operasi di luar upah nelayan (ABK) terhadap biaya total disajikan pada Tabel 3. 
$\underline{\text { Tabel 3, Biaya Variabel KM. Inka Mina } 992}$

\begin{tabular}{|c|c|c|c|c|c|c|c|}
\hline No. & Jenis Biaya & $\begin{array}{l}\text { Jumlah/ } \\
\text { Trip }\end{array}$ & Unit & $\begin{array}{l}\text { Harga } \\
\text { Satuan }\end{array}$ & $\begin{array}{l}\text { Trip/ } \\
\text { Bulan }\end{array}$ & Jumlah & $\%$ \\
\hline 1 & Konsumsi & 525,000 & per Trip & 525,000 & 8 & $50,400,000$ & 16.59 \\
\hline 2 & BBM & 4 & Drum & 7,000 & 8 & $2,688,000$ & 0.88 \\
\hline 3 & Upah Nelayan & 12 & Bulan & $7,500,000$ & 8 & $90,000,000$ & 29.63 \\
\hline 4 & Es & 68 & Balok & 20,000 & 8 & $130,560,000$ & 42.98 \\
\hline 5 & Air Minum & 2 & Galon & 7,000 & 8 & $1,344,000$ & 0.44 \\
\hline 6 & Lain-lain & 300,000 & per Trip & 300,000 & 8 & $28,800,000$ & 9.48 \\
\hline \multicolumn{6}{|c|}{ Total (Rp.) } & $303,792,000$ & \\
\hline
\end{tabular}

Tabel 4. Upah Nelayan (ABK) KM. Inka Mina 992

\begin{tabular}{clcclcc}
\hline No. & Jabatan & $\begin{array}{l}\text { Jumlah } \\
\text { (Orang) }\end{array}$ & Unit & $\begin{array}{l}\text { Harga } \\
\text { Satuan }\end{array}$ & $\begin{array}{c}\text { Persentase } \\
\text { (\%) }\end{array}$ & Nilai (Rp.) \\
\hline 1 & Nakhoda & 1 & Org & $1,500,000$ & 8.7 & $18,000,000$ \\
2 & KKM & 1 & Org & $1,500,000$ & 8.7 & $18,000,000$ \\
3 & Boi-Boi & 1 & Org & $1,500,000$ & 6.52 & $18,000,000$ \\
4 & Pemancing & 16 & Org & $1,500,000$ & 69.57 & $18,000,000$ \\
5 & Koki & 1 & Org & $1,500,000$ & 6.52 & $18,000,000$ \\
\hline & Total & $\mathbf{2 0}$ & & & & $\mathbf{9 0 , 0 0 0 , 0 0 0}$ \\
\hline
\end{tabular}

Hasil analisis menunjukkan bahwa komponen biaya variable terbesar adalah pembelian es balok, yakni 42.98 \%, kemudian upah nelayan (ABK) sebesar 29.63\% dan Konsumsi sebesar 16.59\%. Komponen biaya variable paling kecil pada kapal KM. inka Mina 992 adalah air minum dan BBM yakni $0.44 \%$ dan $0.88 \%$. Upah nelayan (ABK) pada perikanan kapal KM. Inka Mina 992, di dihitung berdasarkan sistem pemberian gaji (Tabel 4), dimana semua kru kapal menerima gaji per bulan adalah sebesar Rp. 1.500.000,- per bulan. Besarnya komponen pembelian es balok pada penelitian ini hamper mencapai setengah dari total biaya variabel.

\subsubsection{Pendapatan}

Pendapatan yang diperoleh pada usaha perikanan kapal KM. Inka Mina 992 di lokasi penelitian adalah bagian yang merupakan hak pemilik kapal kemudian dikurangi biaya tetap, sisanya merupakan keuntungan usaha. Untuk mengetahui besarnya pendapatan dan keuntungan yang diperoleh, maka pada penelitian ini dilakukan perhitungan terhadap jmulah produksi dan harga ikan dari hasil tangkapan kapal KM. Inka Mina dengan data harian selama setahun. Hasil perhitungan disajikan pada Tabel 5.

Tabel 5. Total Penerimaan, Biaya dan Keuntungan Setahun KM. Inka Mina 992

\begin{tabular}{|c|c|c|c|c|}
\hline No & Jenis Item & $\begin{array}{c}\text { Produksi } \\
\text { (kg/Tahun) }\end{array}$ & $\begin{array}{c}\text { Harga } \\
\text { (Rp/Kg) }\end{array}$ & $\begin{array}{l}\text { Penerimaan } \\
\text { (Rp/Tahun) }\end{array}$ \\
\hline 1 & Produksi Ikan cakalang & 84.000 & 35.000 & 2.940 .000 .000 \\
\hline 2 & Biaya Operasi & & & 303.792 .000 \\
\hline 3 & Biaya Tetap & & & 103.029 .250 \\
\hline \multirow[t]{2}{*}{4} & Total biaya $(2+3)$ & & & 406.821 .250 \\
\hline & & Kel & Ingan (Rp.) & $2.533 .178,750$ \\
\hline
\end{tabular}

Hasil analisis menunjukkan bahwa pendapatan rata-rata per tahun kapal KM. Inka Mina 992 yang beroperasi dan ber home base di PPN Ternate adalah sebesar Rp. 2,940,000,000,- yang didapat dari hasil penjualan produk hasil tangkapan ikan cakalang sebanyak 84.000 ton dikalikan dengan ratarata harga ikan cakalang per kg sebesar Rp. 35.000,-. Hasil penerimaan tersebut jika dikurangi dengan total biaya operasioanal sebesar Rp. 406.821.250,-, yang terdiri dari biaya operasi sebesar Rp. 
303.792.000,- dan biaya tetap sebesar 103.029.250,- maka keuntungan bersih yang didapat adalah Rp. 2.533.178.750,-.

\subsection{Kelayakan Usaha}

Penangkapan ikan komersil bertujuan untuk mendapatkan keuntungan, oleh karena itu setiap pemilik kapal tangkap menghendaki pendapatan dari penjualan hasil tangkapan akan melebihi biaya operasi. Cara yang dilakukan oleh setiap pemilik kapal penangkap dalam menangani usaha penangkapan adalah bagaimana menduga biaya dan pendapatan. Dari perkiraan biaya dan pendapatan tersebut, pemilik kapal dapat meramalkan berapa banyaknya keuntungan yang akan diperoleh dari setiap kegiatan operasi penangkapan.

Data produksi oleh kapal pole and line perlu dianalisis untuk menentukan kelayakan finansialnya, terutama jika usaha itu ingin dikembangkan. Studi kelayakan usaha adalah salah satu studi untuk menilai terhadap proyek tertentu yang sedang atau akan dilaksanakan (Kadariah, 1978). Terdapat empat metode yang biasa dipertimbangkan dalam penilaian aliran kas dari suatu investasi agar dapat mengukur nilai investasi mana yang layak untuk dikembangkan dari ke-5 unit usaha pole and line. Keempat metode yang digunakan dalam penelitian ini adalah Net Present Value (NPV), Internal Rate of Return (IRR), Benefit Cost Ratio (B/C) dan Payback Period (PP), Haulussy (2019). Hasil perhitungan kriteria investasi dari ke-5 unit usaha pole and line dapat dilihat pada Tabel 6.

Tabel 6. Nilai Analisis Finansial Kapal KM. Inka Mina 992.

\begin{tabular}{clc}
\hline No. & Kriteria & Nilai \\
\hline 1 & NPV (Rp.) & 187.765 .286$. \\
2 & IRR (\%) & 15.47 \\
3 & B/C Ratio & 1.98 \\
4 & PP (Tahun) & 1.28 \\
\hline
\end{tabular}

\subsubsection{Net Present Value (NPV)}

Nilai NPV kapal KM. Inka Mina 992, pada Tabel 6 adalah sebesar Rp. 103.029.250 yang mengindikasikan bahwa keuntungan sebesar Rp. 2.533.178.750,-.diperoleh oleh kapal pole and line KM. Inka Mina 992 selama 5 tahun mendatang berdasarkan nilai waktu uang sekarang (present value of money), karena nilai NPV >0, maka usaha dikatakan layak untuk dilanjutkan.

\subsubsection{Internal Rate of Return (IRR)}

Discount rate yang digunakan berdasarkan tingkat suku bunga bank sebesar $10 \%$ per tahun. Hasil analisis menunjukan bahwa tingkat diskonto IRR unit usaha kapal pole and line KM. Inka Mina 992 lebih besar dari social discount yaitu 10\%, dengan demikian keputusan berinvestasi pada usaha pole and line KM. Inka Mina 992 lebih menguntungkan dibanding jika dana tersebut disimpan di bank (Tabel 6).

\subsubsection{Benefit Cost Ratio (B/C)}

Hasil analisis menunjukan bahwa unit usaha kapal pole and line KM. Inka Mina 992, memiliki nilai B/C yang menguntungkan dikarenakan nilai B/C Kapal KM. Inka Mina 992 >1.

\subsubsection{Payback Period (PP)}

Hasil analisis Payback Period (Tabel 6) menunjukan bahwa nilai yang diperoleh adalah sebesar 1.28, dimana ini dapat di bahwa dalam jangka waktu 1.28 tahun usaha pole and line KM. Inka Mina 992 sudah dapat membayar kembali semua biaya yang telah dikeluarkan.

\section{PENUTUP}

Kesimpulan dari penelitian tentang Analisis Kelayakan Finansial Usaha Perikanan Pole And Line Di PPN Kota Terntae: Pengoperasian Kapal Pole And Line di PPN Kota Ternate adalah one day fishing. Nelayan berangkat dari fishing base pukul 05.00 pagi dan kembali siang hari pada pukul 13.00. wit Pengoperasian dibagi dalam tiga tahap yaitu tahap penentuaan daerah penangkapan ikan (fishing ground).

Berdasarkan analisis biaya dan keuntungan usaha perikanan Pole And Line di PPN Kota Ternate didapatkan biaya total rata-rata Rp. 406.821.250- , penerimaan rata-rata Rp. 103.029.250,dan keuntungan rata-rata Rp. 2.533.178.750. Berdasarkan analisis finansial usaha perikanan Pole and 
Line di PPN Kota Ternate didapatkan nilai NPV rata-rata Rp. 2.533.178.750,-; B/C ratio rata-rata 1,28; IRR rata-rata $76 \%$ dan PP (Payback Periode) ratarata 1,11 tahun, yang berarti usaha perikanan tangkap Pole and Line dilanjutkan. Berdasarkan kesimpulan yang didapatkan, maka saran yang dapat disampaikan adalah Penambahan alat bantu penangkapan seperti GPS, fasilitas pelabuhan dan fish finder pada kapal Pole and Line untuk meningkatkan hasil produksi. Perlu adanya penelitian lebih lanjut tentang perikanan di PPN Kota Ternate yang di kaji dari berbagai aspek secara terpadu.

\section{DAFTAR PUSTAKA}

Apridar dkk 2011. Ekonomi Kelautan dan Pesisir Yogyakarta Graha Ilmu Damajanti, Irma. (2006). Psikologi Seni. Bandung: PT. Kiblat Buku Utama.

Dahlan, M. Nizar. 2011. Pembangunan Perikanan tangkap di Kabupaten Belitung: Suatu Analisis Tradeoff Ekonomi berbasis Lokal. (Thesis). Sekolah Pasca Sarjana Institut Pertanian Bogor.

FAO. 1983. Species Cataloque. Vol. 2. Scombrids of the Word. An Annoted and Illustrated Cataloque of Tunas, Mackerals, Bonito, and Related Species Known to Date. United Nations Development Program Food and Agriculture Organization of the United Nations. FAO Fisheries Synopsis. No. 125, Volume 2. 1983.

Gunarso, W. 1985. Tingkah Laku Ikan dalam Hubungannya dengan Alat, Metode dan Taktik Penangkapan. Bogor: Fakultas Perikanan. Institut Pertanian Bogor. 149 hal.

Haulussy, F. W. M. 2019. Kelayakan Usaha Pole And Line di Negeri Hative Kecil Kota Ambon. Jurnal PAPALELE Vol. 3 (1): 21-30.

Hermanto F. 1998. Ilmu Usaha Tani. Penebar Swadaya. Jakarta.

Imron, Masyhuri (ed) 2001, Pemberdayaan Masyarakat Nelayan. Yogyakarta, Media Pressindo.

Istiqlaliyah, Muflikhati. (2010). Kondisi Sosial Ekonomi dan Tingkat Kesejahteraan Keluarga: Kasus di Wilayah Pasisir Jawa Barat, dalam Jurnal Ilmu Keluarga. IPB Bogor. Januari 2010. 1 - 10.

Jhingan M.L.2003, Pembangunan Perencanaan Jakarta Terbitan: Rajagrafindo persada; 2003, 2003.

Kusnadi 2003. Kemiskinan Nelayan Ditinjau Teori social. Yayasan Pustaka Obor Indonesia.

Kadariah 1978. Evaluasi Proyek. Analisis Ekonomi. Edisi ke dua. Penerbit Fakultas Ekonomi Universitas Indonesia.

Kementrain Kelautan dan Perikanan RI. (2013). Profil Kelautan Perikanan Provinsi Maluku untuk Mendukung Industria-lisasi KP. Pusat Data Statistik dan Informasi Sekretariat Jenderal KKP RI (2013).

Nontji A. 1993. Laut Nusantara. Jakarta: Penerbit Djambatan.368 hal.

Mulyadi, 2005 ekonomi kelautan. Penerbit PT. Raja Grafindo Persada: Jakarta.

Mubyarto 2002, Nelayan dan Kemiskinan Studi Ekonomi di Dua Pantai. CV Rajawali Press, Jakarta.

Matsumoto WM, SkillmanRA, and DizonAE.1984. Synopsis of biological data on skipjack tuna, Katsuwonus pelamis . U.S. Dep. Commer., NOAA Tech. Rep. NMFS Circ. 451, 92.

Richard G. Lipsey dan Peter O. Steiner 1991, Pengantar Makroekonomi Penerbit Erlanga.

Sastrawidjaya. 2002, Nelayan dan Kemiskinan, Penerbit Pradnya Jakarta.

Soekartiwi .2002 Agrbisnis Teori Dan Aplikasinya. Raja Grafindo, Jakarta.

Soeharto I. (1999). Manajemen Proyek. Dari Konseptual sampai Operasional. Jilid 1. Konsep Studi Kelayakan dan Jaringan Kerja. Penerbit Erlangga. Pp. 356.

Todaro, 2002, Pembangunan Ekonomi Bumi Aksara Jakarta. Penerbit Erlanga.

Umar, H. 2003. Studi Kelayakan dalam Bisnis Jasa. PT Gramedia Pustaka Utama. Jakarta.

Usemahu AR, Tomasila L. 2003. Teknik Penangkapan Ikan. Jakarta :Departemen Kelautan dan Perikanan Pusat.

Waileruny W. 2014. Pemanfaatan Berkelanjutan Sumberdaya Perikanan Cakalang di Laut Banda dan Sekitarnya, Provinsi Maluku. Disertasi. Sekolah Pascasarjana Institut Pertanian Bogor 132 hal.

Waileruny, W. dan (1), Dinatonia J. Matruty, D. J. 2015. Analisis Finansial Usaha Penangkapan Ikan Cakalang Dengan Alat Tangkap Pole And Line Di Muluku - Indonesia. Jurnal Amanisal PSP Unpatti FPIK Unpatti-Ambon. Vol. 4. (1):1-9. 